\title{
Guillermina del Valle Pavón, Donativos, préstamos y privilegios. Los mercaderes y mineros de la ciudad de México durante la guerra Anglo-Española de 1779-1783, México, Instituto de Investigaciones Dr. José María Luis Mora, 2016.
}

\author{
Eduardo Flores Clair*
}

2 de agosto de 2017

\begin{abstract}
Cuillermina del Valle nos ofrece un libro que ahonda en las causas del derrum$\checkmark$ be del imperio español. La historiografía contemporánea dedicada al "precio de la guerra" en el último tercio del siglo XVIII ha realizado notables avances. Según Barbier y Klein (1985, p. 490), durante el reinado de Carlos III, casi tres quintas partes del gasto eran destinadas al ejército y la marina, lo que generó un insalvable déficit presupuestal. ${ }^{1}$ Carlos Marichal (1999), ${ }^{2}$ abordó la pronunciada crisis provocada por la insolvencia económica, el agotamiento de las fuentes tradicionales de crédito y la insuficiente recaudación fiscal. En la guerra, los imperios se disputaban los recursos naturales y los vastos mercados americanos.

Los conflictos bélicos son el telón de fondo que le permiten a Guillermina del Valle presentarnos una historia de comerciantes y mineros novohispanos que unieron su destino a la corona para evitar la destrucción colonial y encarar los conflictos internacionales, por medio del apoyo económico anhelaban incrementar la capacidad militar y mantener intacto el sistema monárquico que les había permitido enriquecerse. Por su parte la corona, para conseguir recursos, implementó en la metrópoli un instrumento para financiar la guerra, basado en los donativos de par-

\footnotetext{
*Instituto Nacional de Antropología e Historia.

${ }^{1}$ J. A. Barbier y H. S. Klein (1985). Las prioridades de un monarca ilustrado: el gasto público bajo el reinado de Carlos III. Revista de Historia Económica, 3(3), 473-495.

${ }^{2}$ C. Marichal (1999). La bancarrota del virreinato. Nueva España y las finanzas del Imperio Español, 1780-1810. México: Fondo de Cultura Económica.
} 
ticulares, los impuestos de Hacienda y la deuda nacional. ${ }^{3}$ Exportó este modelo a las colonias y, en Donativos, préstamos y privilegios se analiza de manera detallada y se revelan los nombres y apellidos de todos aquellos patriotas que ayudaron a la monarquía en su desgracia. ${ }^{4}$

Sobra decir que la Armada española requería de una descomunal inversión económica. El desarrollo económico y el poder militar de Inglaterra y Francia eran superiores a los recursos materiales con los que contaba España y sus colonias; las innovaciones tecnológicas de las máquinas de guerra -navíos- a los imperios les proporcionaron una desmedida capacidad de combate. Los ingleses, por su parte, adoptaron un modelo de financiamiento de la guerra distinto al de los ibéricos; involucraron a la extensa flota mercante y a los fabricantes particulares de armas. En cambio los borbones incrementaron su inversión en las fábricas reales, con lo cual generaron un mayor déficit presupuestal que arrastraban desde varias décadas atrás y el pago de la deuda se hizo insostenible. Para detener la angustia, las autoridades coloniales buscaron por todos los rincones la riqueza y ahorros acumulados.

En este sentido, Guillermina del Valle revela el hecho de que el Consulado de Comerciantes había acumulado una bolsa secreta con las "sobras de alcabalas" que ascendía a la cuantiosa suma de más de 1000000 de pesos. Después de unas complejas averiguaciones, donde se patentizó la protección del rey, los comerciantes recibieron el reconocimiento por el donativo de 300000 pesos, con el compromiso de que un navío llevaría el nombre de San Hipólito, santo patrono de la ciudad de México y por gratitud se le conocería como El Mexicano.

En el cabildeo y negociación de los préstamos, la corona difundía un discurso que apelaba a los sentimientos y al patriotismo, pedía que los vasallos actuaran según "les dicte su corazón". Los súbditos solían gritar "salvemos al rey", pero a cambio esperaban que el favor se les retribuyera de muy diversa manera, con concesiones, apoyos especiales, títulos de nobleza, pero sobre todo posibilidades de negocios a través de la monopolización de ciertas mercancías que les produjeran cuantiosas ganancias. En este sentido, la autora analiza de manera puntual el caso de la concesión del comercio de cacao de Guayaquil con destino a los paladares novohispanos. Los Yraeta e Icaza encontraron a través del chocolate un nicho de mercado en el Pacífico, que abrió nuevas rutas de comercio, permitió un intercambio en los distintos puertos del mar del sur y acercó al mercado de Oriente. Como bien afirma Guillermina del Valle: "la configuración de las redes

\footnotetext{
${ }^{3}$ R. Torres Sánchez (2013). El precio de la guerra. El Estado fiscal-militar de Carlos III (17791783). Madrid: Marcial Pons.

${ }^{4}$ En este sentido, véase para el caso de Argentina a J. Kraselsky (2016). Las Corporaciones Mercantiles de Buenos Aires y los préstamos y donativos graciosos, 1748-1806. Illes i Imperis, $18,107-134$.
} 
de negocios, la familia patriarcal, las lealtades de parentesco, oriundez y amistad resultaban cruciales para el ascenso social y el prestigio de los grandes mercaderes".

Donativos, préstamos y privilegios examina a otro sector pudiente de la sociedad novohispana. Nos referimos a los mineros, quienes gozaron de una política de fomento que se tradujo en el derecho de organizarse a través de un Tribunal, contar con "modernas" ordenanzas del gremio, ejercer la justicia por propia mano en los asuntos mineros. Sobre todo, favoreció una política de fomento que, entre otros aspectos, promovió una cuantiosa reducción de varias mercancías monopolizadas por la corona, como el mercurio, la pólvora y la sal. Especialmente se beneficiaron de la exención del impuesto de la alcabala de "los utensilios, objetos y frutos" que se consumían en el proceso productivo minero. Con los años, fue tan grande el descalabro del fondo minero causado por los préstamos a la corona, que la hipoteca y los intereses se prolongaron por décadas, hasta formar parte de la deuda nacional durante el siglo XIX.

En términos particulares, el minero que aportó mayores recursos a la monarquía fue Pedro Romero de Terreros, quien costeó un navío de línea de 112 cañones, construido en el astillero de La Habana, con una capacidad para más de 800 hombres. En 1786 se lanzó al mar y participó en distintas batallas; sobrevivió hasta 1811, cuando se decidió su deshuese en el arsenal de la Carraca. Romero de Terreros consiguió para su familia tres títulos de nobleza: Conde de Regla, Marqués de San Francisco y Marqués de San Cristóbal, pero sobre todo obtuvo la concesión de abrir las puertas del Monte Pío, institución muy lucrativa dedicada al préstamo prendario que hasta nuestros días goza de plena salud.

Uno de los aportes más significativos de Donativos, préstamos y privilegios es la sociología de los comerciantes que quedan reflejados a través de una serie de cuadros. En ellos se aprecian las características que distinguían a los mercaderes novohispanos. Es posible sugerir que los donativos son una especie de indicador que permite medir el patriotismo de estos vendedores, desde los almacenistas más encumbrados hasta los más modestos puesteros que realizaron aportaciones de tan sólo un par de pesos. Resulta importante resaltar que, entre los prestamistas, se identifica a un grupo sobresaliente de mujeres, quienes eran empresarias y llevaban las riendas de los negocios familiares, por ejemplo: María Anna González de Agüero, María Martínez de Velazco, Claudia Rodríguez de Rivas, Francisca Fernández Madrid, entre otras.

En general, el libro es un importante aporte a nuestra historiografía, los comerciantes y mineros fueron grupos que desempeñaron un papel muy significativo en la historia colonial. No sólo por su riqueza, como demuestra Guillermina del Valle, formaron una estructura corporativa que compartía el poder en diferentes ámbitos con el rey, quien se fue debilitando hasta extinguirse. Es muy probable, que todos aquellos que colaboraron con sus contribuciones económicas, sin im- 
portar el monto, sintieran un gran orgullo el poder colaborar con la monarquía y sobre todo, sabiendo que su nombre se conocería a través de los listados que publicaba la Gazeta de México. 